\title{
The influence of collaboration-oriented organisational capabilities on supply chain competence among small and medium enterprises
}

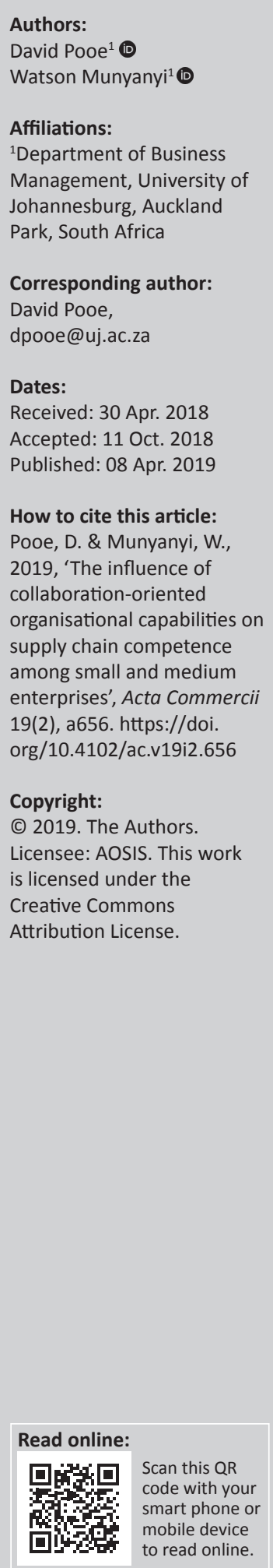

Orientation: In the contemporary business environment, there is need for firms to strategically interact with partners beyond boundaries, and by collaborating these firms can access resource and technologies beyond their limits.

Research purpose: The aim of this study was to investigate the influence of collaborationoriented organisational capabilities (COOC) on supply chain competence among small and medium enterprises (SMEs) in Zimbabwe.

Motivation for the study: Small and medium enterprises in Zimbabwe have experienced limited growth, primarily because of their failure to nurture and steer their competencies. The literature suggests that there is value in synchronised cooperative and competitive interactions between firms as such interactions incentivise the pursuit of shared interests.

Research design, approach and method: Through a cross-sectional survey, data were collected from 388 SMEs in Zimbabwe, and structural equation modelling was used to analyse the data.

Main findings: The study specifically found that there is a positive and significant relationship between collaboration-oriented capabilities and supply chain competence.

Practical/managerial implications: The results of this study demonstrate the critical role of organisational capabilities in achieving supply chain competence. The study proves that collaborative capabilities are central to the supply chain success of SMEs, with the possibility of influencing also the firm's sustainable competitive advantage in line with the dynamic capabilities theory.

Contribution/value-add: This study sheds light on the possibility of enhancing the overall supply chain competence of SMEs by establishing and empirically testing the relationships between COOC and supply chain competence.

Keywords: customer interaction management capability; partnering proactiveness; supply chain competence; alliance management capability; SMEs; small and medium enterprises.

\section{Introduction and background}

In Zimbabwe, like in most developing economies, there has been a significant increase in the number of small and medium enterprises (SMEs) over the last two decades (Macheka et al. 2013:127). In Zimbabwe, the company closures that characterised the last two decades have led to the collapse in formal employment, leaving the SME sector as the biggest provider of livelihood to families and the engine for economic transformation (Manuere \& Majoni 2016:63). These SMEs now constitute a noticeable portion of the total businesses in most economies, and in some countries, they are now the primary source of income for approximately $80 \%$ of the population (Kato \& Charoenrat 2018:578). In addition, the affirmative action and indigenous laws, enforced in Zimbabwe since the independence in 1980, have led to the sprouting of several SMEs across all sectors of the economy (Nyangara 2013:219). Although SMEs are recognised as central to the economic growth of many countries, they continue to suffer from a number of challenges. Small and medium enterprises worldwide face increased global competition, limited access to finance and business and managerial incompetencies, and these have hindered their growth (Löfsten 2016:324; Smit \& Watkins 2012:6324). These challenges have also led to the collapse of many SMEs, and those that survive do not show satisfactory growth. Because of this stunted growth in the SME sector and the global significance of SMEs, understanding their performance and efficiency stimuli is key concern for organisational strategy and policy formulation (Rahmandad \& Repenning 2016:649). Undermining the SME sector in strategy and policy formulation will not 
only affect their long-term survival but is also a failure to recognise that some large firms evolved from these SMEs (Frank \& Roessl 2015:227).

In modern business settings, most of the critical skills and resources for growth now lie beyond the firm's boundaries, and outside of the firm's direct control and firms must have the right form of governance to access these (Niesten et al. 2017:3). Small and medium enterprises face peculiar challenges that make it necessary to seek external collaboration to improve their efficiency and access to resources through cooperation (Franco \& Haase 2015:168). Such challenges include limited access to formalised financing from financial markets and cumbersome operational regulations (Osano \& Languitone 2016:7; Peck, Jackson \& Mulvey 2018:29). In this regard, establishing and maintaining strong interfirm collaborations increasingly become significant for SMEs as they seek to confront globalisation and increased competition (Tan \& Liu 2014:420). Most SMEs rely on external information in business decision-making; hence SMEs cannot survive in isolation. By creating alliances and collaborations, firms are able to effectively manage uncertainty in the business environment, proactively reposition themselves in these competitive markets and reduce operational costs (O'Dwyer \& Gilmore 2018:58; Pooe \& Mathu 2011:321). Collaboration entails working across organisational limits to build and manage exclusive value addition processes, shared resources, people and technology, and eventually create synergies for competitive advantage. By collaborating, firms create valuable unions at strategic, tactical and operational levels to achieve better planning, forecasting and information, resources and incentive sharing (Ramanathan \& Muyldermans 2010:219). Collaboration-oriented organisational capabilities (COOC) incorporate alliance management capability, structural integration capability, supply chain agility, knowledge management capability and internalisation capability (Kohtamäki, Rabetino \& Möller 2018:188).

As the principal focus of a firm is to maintain a competitive position, modern firms should improve their interaction with their stakeholders and monitor production and delivery processes (Büyüközkan \& Göçer 2018:157). As the business environmental conditions have increasingly become impulsive, supply chain competence has become critical for the survival of firms (Kim \& Chai 2017:43). Supply chain competence to the capacity of a firm to manage its technical, production, and managerial skills support the firm's supply chain (Ngai, Chau \& Chan 2011:234). Empirical researchers believe that supply chain competence has the potential to increase both operational excellence and customer relationship and consequently firm performance (Rai, Patnayakuni \& Seth 2006:225). It enables firms to positively respond to unforeseen environmental changes and translate these changes into opportunities for expansion and growth (Swafford, Ghosh \& Murthy 2008:288). There is value in synchronised cooperative and competitive interactions between firms, as such interactions incentivise the pursuit of shared interests (Niesten \& Jolink 2015:81). However, there is limited and inconclusive empirical evidence on the antecedence and dynamics of supply chain interaction and competence development. As stated by Luo, Rindfleisch and Tse (2007:73), research on supply chain capabilities has remained incomplete and imperfect to lead to an understanding of the complex process that lead to alliance activities with competitors, as well as supply chain competencies. As a result, managers and owners of firms are left with limited strategic management indicators on how firms can improve supply chain performance through collaboration and alliances. Most supply chain literature has dedicated substantial attention to understanding the antecedents of collaborative relationships without linking them to supply chain performance and value creation, the performance actions that improve the worth of a firm and its products and services (Chen, Preston \& Swink 2015:6; Pang et al. 2015:289; Ramon-Jeronimo, Florez-Lopez \& RamonJeronimo 2017:1488). In this regard, this study seeks to investigate the influence of COOC, namely customer interaction management capability, alliance management capability and partnering proactiveness on supply chain competence in Zimbabwean SMEs.

Drawing on the both the network theory and the dynamic capabilities theory, as a specific strand of the resource-based view (RBV), this study investigates the influence of COOC on supply competence. By elaborating on the influence of organisational capabilities on supply chain competence, the study contributes to the existing literature by pointing out the significance of the collaboration-oriented capabilities in understanding supply chain competence. The study addressed COOC by theoretically conceptualising the capabilities, their dimensions and empirically validating the constructs. This aids in providing a clearer understanding of the managerial practices that SMEs should undertake to ensure supply chain competence and eventually organisational success. The research was conducted in the SME context because SMEs play a significant role in the economic development of many countries (De Wit \& De Kok 2014:283). It is critical that studies on capabilities be undertaken in the Zimbabwean SMEs context because there is limited research in this area, and no study has been carried out on supply chain competence in the Zimbabwean context.

\section{Literature review Organisational capabilities}

One of the popular notional viewpoints on firm competitiveness in strategic management is the RBV. The RBV, from which the dynamic capabilities theory emanates, postulates that organisational capabilities are a potential source of sustainable competitive edge and superior performance (Barney 2001:42; Wernerfelt 1984:171). According to Winter (2003:991), capability refers to the processes and procedures that are established and behaviours that are learned by a firm that is extremely patterned, repetitive and is founded partly in tacit knowledge. In line with the dynamic capabilities theory, organisational assets are the resource endowments of the firm, while capabilities act as the glue that binds assets together and facilitates effective deployment of these resources (Hooley, Broderick \& Möller 
1998:98). Teece (2014:17) posits that while resources or assets are essential it should be instantly clear to firms that, in today's dynamic and competitive environments, resources alone are mostly of fleeting value when compared to capabilities. Organisational capabilities represent a dynamic capability that firms can use to positively react to environmental changes, for instance through habitually updating objectives to reflect changes in the business environments and new resource configurations for product, process or the customer relationship development (Forkmann et al. 2016:186). Dynamic capabilities are critical in a firm setting because they determine the speed and degree at which the firm's resources are manipulated to match environmental requirements and opportunities, thereby generating sustainable competitive advantage (Teece 2012:1395).

\section{Customer interaction management capability}

Customer interaction management capability relates to the firm's capability to identify, attain and retain profitable customers. This capability enables the firm to collect and collate customer transactional data and develop customer profiles based on their purchasing behaviour (Mukerjee 2012:50). Today's business setting is increasingly becoming competitive and dynamic while organisational resources are becoming largely constrained (Martinez-Conesa, Soto-Acosta \& Carayannis 2017:554). In addition, intense competition and delicate customer expectations coupled with increased customer defection are negatively impacting on the firm's efforts to build customer loyalty, hindering sustained viability and growth (Tsou \& Huang 2018:1288). This makes it necessary for firms that seek to be successful to create and maintain sound business relationships with their customers. Customer involvement is continually becoming the foundation for competitive lead and firms are urged to enhance and facilitate customer participation in organisational activities (Homburg, Jozić \& Kuehnl 2017:3). Firms that develop superior customer-focused business strategies are highly likely to increase their market share and attain a competitive advantage (Lin et al. 2016:21). This makes it important for firms to increase and manage their interaction with existing and future customers. Firms need to participate in regular and planned interactions with customers. This will assist in the development of customer acquaintances and other relational and logical assets that enable firms to comprehend better the changes in customer needs changes and respond appropriately (Racela 2014:18). In principle, satisfied customers are key to a firm's financial performance; hence, firms need to continuously evaluate the level of customer satisfaction (Andaleeb, Rashid \& Rahman 2016:460).

\section{Partnering proactiveness}

Partnering proactiveness refers to the firm's capability to realise and respond to the new alliances opportunities that increase access to resources ahead of its competition (Castro \& Roldán 2015: Sarkar, Aulakh \& Madhok 2009:586). Over the years, firms have resorted to forming complex relationship networks with multiple and diverse business partners as a way of both improving their resource bases and surviving turbulent business environments (Liu 2017:553). The business-to-business environment continues to be increasingly turbulent owing to the complex techno-socioeconomic changes such as technological sophistication, globalisation, economic crises and complicated relationships and networks complexities (Mattsson, Corsaro \& Ramos 2015:8). Partnerships are formed between two or more firms that decide to come together as a way of enhancing the achievement of their objectives that each firm on its own would find it difficult to easily achieve (Valença \& Alves 2017:77). Partnering is a deliberate business strategy where firms that have a reciprocated interdependence decide to share compatible goals and benefits and the ability of firms to proactively identify partnering opportunities is a key factor for success (Raja, Green \& Leiringer 2010:260). According to Wang and Rajagopalan (2015:251), firms that exhibit partnering proactiveness are more likely to create value through complementary assets and learning and better management of conflict and unexpected contingencies. Proactive firms enjoy first-mover advantages leading to greater market performance (Sarkar et al. 2009:587).

\section{Alliance management capability}

Over the last two decades, interfirm alliances have become more significant in strengthening the company's competitive position (Sluyts et al. 2011:875). Alliances can be used by firms to develop an assortment of valuable resources that a firm may not be able to create autonomously. Storbacka (2012:259) argues that firms should possess an alliance capability to expand operational performance and eventually create value for the shareholders. Purposive relationships between two or more independent firms enable the exchange of resources and co-development of capabilities for the realisation of mutually pertinent benefits (Kale \& Singh 2009:46). Building on the literature alliance management capability has been defined as the firm's ability to manage strategic business relationships using proper processes such as coalition target setting, task implementation and evaluation to achieve shared benefits (Kohtamäki et al. 2018:191). From the viewpoint of the RBV of the firm, alliance management capabilities are being viewed as heterogeneous and permanent resources and because of their value, rarity, inimitability and no substitutability, these capabilities constitute a potentially important source of sustained competitive advantage. By creating and assimilating the knowledge on alliances, firms are able to develop management capabilities that empower them to manage business relationships more effectively (Sluyts et al. 2011:875).

\section{Supply chain competence}

A competence has been defined as a set of abilities, skills and technologies, which is difficult to imitate and which the firm performs better than its competitors, thereby providing a competitive advantage (Coates \& McDermott 2002:436). The interconnection among sellers, manufacturers, traders, suppliers and customers in which raw material, capital and information flow multilaterally among these participants is 


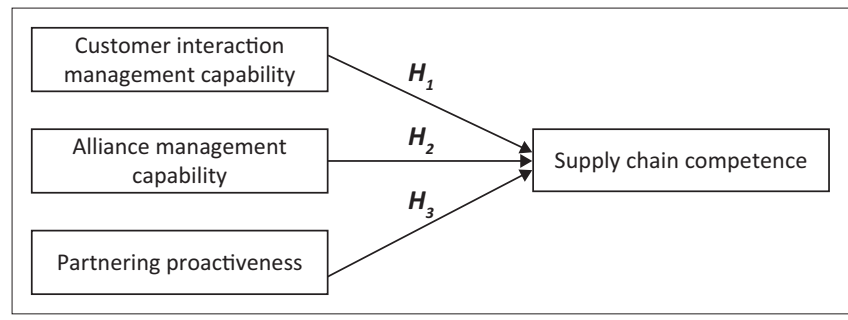

FIGURE 1: Conceptual model.

referred to as the supply chain (Costantino et al. 2015:127). In a supply chain, there is intense and organised coordination, planning and controlling of products and services between the various players in the chain (Büyüközkan \& Göçer 2018:157). Supply chain competence therefore relates to the ability to manage technological, production and management skills that support the supply chain (Ngai et al. 2011:234). As the business environment continues to become intensely knowledge based, firms that invest in supply chain competencies strategically position themselves for superior performance (Chan, Ngai \& Moon 2017:491). Supply chain competence is a lasting resource for a firm's competitive strength that also promotes value addition positive unification and configuration of a firm's functions towards its strategic objectives (Pettersson \& Segerstedt 2013:357).

\section{Conceptual model}

The following conceptual model illustrates the dimensions of COOC and the hypothesised impact they have on supply chain competence. Collaborative supply chain management represents the next step in the evolution of supply chain management (Hugo 2018:239) and this motivated the focus on collaboration-oriented capabilities in this study. The development of the conceptual model was based on a review of and integration and learning from existing literature (Figure 1).

\section{Hypothesis development Customer interaction management capability and supply chain competence}

To successfully manage operations, firms must obtain regular market information, and create and sustain high-quality relationships that make it easier for the firm to flexibly respond to environmental changes (Najafi-Tavani et al. 2018:475). Higher relationship quality positively influences both knowledge sharing and responsive capability, and quality interaction with customers has been identified as a key source of new service ideas and valuable solutions (Migdadi et al. 2018:182). When interactions with customers are healthy, any changes in customer needs are quickly identified and corresponding changes to the product offerings, technologies, skills or knowledge are undertaken (Forkman et al. 2016:190). This eventually leads to an improvement in the level of customer satisfaction and other firm performance measures. Likewise, supply chain performance depends largely on efficient coordination of the activities undertaken with supply chain partners like customers (Giri \& Sarker 2017:170). When a firm can effectively manage its interaction with customers, it is able to identify new customer needs and adapt accordingly, thereby mitigating the disruptions in the supply chain and improving overall business performance (Lee \& Rha 2016:3). The resources entrenched within the firms must be utilised to react to changing customer demands and to deliver value to customers as a way of refining the supply chain (Forkman et al. 2016:189). The argument above suggests that the ability to manage interactions and relationships with customers is beneficial to the firm as it provides a sustainable basis for continuous improvement of the supply chain management abilities. If customer interaction capabilities help firms to develop and maintain meaningful relationships with customers, then through such interactions, these firms should experience an improvement in their supply chain competences. This leads to the following hypothesis:

H1: There is a positive and significant relationship between customer interaction management capability and supply chain competence.

\section{Alliance management capability and supply chain competence}

According to the RBV, a firm is a configuration of connected resources, capabilities and competencies (Barney 2001:42; Wernerfelt 1984:171). Dosi and Teece (1998:284) define capabilities as a distinguished set of skills, matching assets and business routines that allow a firm to coordinate its activities for competitive advantage. Based on the capabilities view, firms that manage their alliances properly can manage their business processes better than their competitors (Teece 2014:17). When two or more firms enter an alliance, each one of them will gradually learn about the other firm's operations, internal organisation structure and decision-making styles (Niesten \& Jolink 2015:81). This distinctive exchange of knowledge and information between partners becomes an essential ingredient for supply chain management, particularly when it is largely information technology capabilities powered (Rai et al. 2006:225). By cultivating their alliance management capabilities, firms may be contributing to the development of their supply chain competences. Noticeably, how a firm's alliances are coordinated and orchestrated is pertinent to its competitive success (Teece 2014:17). Similar to the evidence that literature provides regarding alliance management, this study proposes that firms are able to better their supply chain competences by improving their alliance management abilities. As such, this study specifically hypothesises the following:

H2: There is a positive and significant relationship between alliance management capability and supply chain competence.

\section{Partnering proactiveness and supply chain competence}

According to Eisenhardt, Furr and Bingham (2010:1271) given the dynamism in the business environment, greater performance largely depends on successfully balancing competence and proactiveness. In these highly networked business environments, it is progressively significant for firms to possess the ability to proactively engage in value 
creation through partnerships, such as combined innovation, marketing alliances and supply chain coordination (Niesten \& Jolink 2015:89). These interfirm partnerships enable the exchange of resources for developing processes, products or services (Pangarkar, Yuan \& Hussain 2017:480). The implication is that partnerships among various firms produce new and synergistic resource combinations among these firms (Eisenhardt \& Martin 2000:1107). Proactive firms therefore are better positioned to create first-mover advantages in distribution channels, product development and supplier management because the majority of SMEs are reactive participants in the value chain, and this is central to achieving sustainable supply chain competence (Wiklund \& Shepherd 2003:1307). The capacity to proactively create, manage and integrate partnership is important for firms that seek to attain value co-creation, innovation and superior supplier and customer management (Sluyts et al. 2011:880). Given these arguments, the following hypothesis is made.

H3: There is a positive and significant relationship between partnering proactiveness and supply chain competence.

\section{Research methodology Research approach and design}

This study adopted a positivistic paradigm in investigating the influence of collaboration-oriented capabilities on supply chain competence. The choice of this paradigm was justified by the need to quantitatively analyse the data to meet the objectives of this study in a more objective manner. A quantitative approach in research is a formal and objective methodical process of describing and testing relationships and examining the cause-effect relations among variables of interest (Burns \& Grove 1993:777). The design used in this study was a cross-sectional survey research design, with the aim of establishing the cause-effect relationship without experimental manipulation. A cross-sectional survey interrogates the variable that pertains to a phenomenon simultaneously and data were systematically rearranged in a manner that allows the description of relationships (Babbie \& Mouton 2001:93). The population of interest in this study was SMEs, and to make the group manageable and feasible, the sampling frame was confined to those SMEs that are members of the SMEs of Zimbabwe (SMEAZ). The SMEAZ is a not-forprofit organisation that represents the needs and aspirations of SMEs and assists in raising capital, finding markets, training and development.

A questionnaire was sent to 832 SMEs, randomly selected from the SMEAZ database of 1664 SMEs. A self-administered questionnaire was used to collect data, and to improve on the response rate, follow-up phone calls and visits were made to those who had not returned the questionnaires. As a result, 388 valid questionnaires were returned, yielding a $46.6 \%$ response rate. Furthermore, this approach presented the researcher with an opportunity to clarify the questions to respondents. The participants were drawn from the various sectors of the economy and from the 10 provinces of
TABLE 1: General characteristics of participants $(N=388)$.

\begin{tabular}{lccc}
\hline Business sector & Frequency & Percentage & Valid (\%) \\
\hline Manufacturing & 83 & 21.40 & 21.40 \\
\hline Retail & 102 & 26.30 & 26.30 \\
\hline Mining & 42 & 10.80 & 10.80 \\
\hline Tourism & 52 & 13.40 & 13.40 \\
\hline Agriculture & 47 & 12.10 & 12.10 \\
\hline Other & 62 & 16.00 & 16.00 \\
No. of employees in organisation & & & \\
0-50 & 204 & 52.60 & 52.60 \\
51-100 & 66 & 17.00 & 17.00 \\
101-150 & 49 & 12.60 & 12.60 \\
151 and more & 69 & 17.01 & 17.01 \\
Business annual turnover & & & \\
\$0-5000 & 145 & 37.40 & 37.40 \\
\$5001-10 000 & 80 & 20.60 & 20.60 \\
\$10 000-15 000 & 88 & 22.70 & 22.70 \\
\$15 001 and more & 75 & 19.30 & 19.30 \\
Years of business operation & & & \\
Less than 5 years & 164 & 42.30 & 42.30 \\
Between 5 and 10 years & 118 & 30.40 & 30.40 \\
More than 10 years & 106 & 27.30 & 27.30 \\
\hline
\end{tabular}

Zimbabwe. The study empirically tested the conceptual model using data collected from owners and managers of the 388 SMEs in Zimbabwe. Table 1 indicates the demographic characteristics of the sample.

\section{Measurement instrument}

A questionnaire was used to collect the data used in this study. The scales for both collaborative-oriented capabilities and supply chain competence were developed in line with the generally recognised principles of a survey research design outlined by Burns and Burns (2008:488) and were predominantly adapted from previously validated instruments in the existing literature. Alliance management capability and partnering proactiveness items were developed following the work of Parida and Örtqvist (2015), customer interaction management capability following the work of Wang and Feng (2012) and supply chain competence was motivated by the studies carried out by Pettersson and Segerstedt (2013) and Ngai et al. (2011). A five-point Likert scale - ranging from 'Strongly disagree' to 'Strongly agree' was used in this study. The choice of a Likert scale questionnaire was motivated by the fact that it is generally easy to use and produces more standardised scales, and that improves on validity and reliability (Babbie \& Mouton 2007:160; Burns \& Burns 2008:475).

\section{Data analysis}

Data analysis refers to the process by which the collected data transformed into a more manageable size to enable the categorisation of behaviours and the application of statistical techniques (Cooper \& Schindler 2016:94). In this study, quantitative methods of data analysis were used. Quantitative data analysis refers to the statistical representation, manipulation and management of research data in a manner that allows the description and explanation of relationships 
that emerge from the observations (Babbie 2005:414). Structural equation modelling (SEM) was used in data analysis and in line with the recommendation of Anderson and Gerbing (1988:411); a two-step approach to SEM was conducted. Firstly, confirmatory factor analysis (CFA) was performed on all of the construct items to determine the validity and reliability of the items used in the study. The second step involved the conceptualisation and testing of the structural model to test the hypotheses made.

\section{Ethical considerations}

Irrespective of the research methods used in a particular study, ethical considerations remain essential. An academic research of this nature involves interacting with people on certain aspects of their lives, hence there is need for the researcher to exercise care to avoid infringing on participants' rights to freedom, anonymity, confidentiality and informed consent (Polit \& Hungler 1999:132-134). Burns and Grove (2010:776) elaborate that informed consent in research pertains to the potential research participant's voluntary agreement to take part in a study, a decision a participant arrives at after receiving all the critical information about a study. The participants who took part in this study were informed of their right to voluntarily consent or decline to participate, and to withdraw participation at any time without penalty. All the rights of participants including the right to anonymity and confidentiality were carefully upheld throughout the study. Anonymity was ensured by ensuring that the respondents cannot be linked, even by the researcher, to their individual responses. The information provided by the respondents was not and will not be publicly reported in a manner that identifies the respondents to ensure confidentiality and, in addition, no names, marks or identities were provided for on the questionnaires, which aided in ensuring adherence to ethical considerations.

\section{Validity and reliability of constructs}

Through CFA validity and reliability of the measurement, the model was tested. Convergent validity measures the extent of correlation of multiple items of the same construct and for it to hold, the average variance extracted (AVE) values must be at least 0.7 , although values of 0.5 are considered acceptable (Fornell \& Larcker 1981:40). In addition, item factor loadings of 0.5 or more confirm convergent validity and so do composite reliability values of 0.7 or more (Hair, Anderson \& Tatham 1987:260). Composite reliability (CR) also informs the researcher both on the reliability and internal consistency of each construct and values of over 0.7 indicate reliability. Table 2 shows that the loadings for each factor surpass the 0.70 cutoff point and factors capture $\mathrm{CR}$ values greater than 0.7 , thus exhibiting adequate reliability and validity. The AVE values ranged between 0.505 and 0.629 which, according to Fornell and Larcker (1981:40), are considered acceptable.

Discriminant validity was also assessed, and it is a measure of the degree to which construct items vary from other construct items. Discriminant validity was also assessed by
TABLE 2: Validity and reliability assessment.

\begin{tabular}{|c|c|c|c|c|}
\hline Construct items & $\begin{array}{c}\text { Factor } \\
\text { loading }\end{array}$ & CR & $\begin{array}{l}\text { Cronbach's } \\
\text { alpha }\end{array}$ & AVE \\
\hline $\begin{array}{l}\text { Customer interaction management } \\
\text { capability }\end{array}$ & - & 0.794 & 0.756 & 0.541 \\
\hline $\begin{array}{l}\text { CIMC1: We regularly meet customers } \\
\text { to learn their current and potential } \\
\text { needs. }\end{array}$ & - & - & - & - \\
\hline $\begin{array}{l}\text { CIMC2: We are good at creating } \\
\text { relationships with key customers. }\end{array}$ & 0.765 & - & - & - \\
\hline $\begin{array}{l}\text { CIMC3: We maintain an interactive } \\
\text { two-way communication with our } \\
\text { customers. }\end{array}$ & 0.744 & - & - & - \\
\hline $\begin{array}{l}\text { CIMC4: We have a continual dialogue } \\
\text { with each customer. }\end{array}$ & 0.739 & - & - & - \\
\hline Alliance management capability & - & 0.833 & 0.783 & 0.555 \\
\hline $\begin{array}{l}\text { AMC1: We conduct periodic reviews of } \\
\text { our networks. }\end{array}$ & 0.802 & - & - & - \\
\hline $\begin{array}{l}\text { AMC2: Our firm modifies its network } \\
\text { procedures as we learn from } \\
\text { experience. }\end{array}$ & 0.736 & - & - & - \\
\hline $\begin{array}{l}\text { AMC3: We ensure that strategic } \\
\text { decisions are informed by our } \\
\text { networking. }\end{array}$ & 0.700 & - & - & - \\
\hline $\begin{array}{l}\text { AMC4: The company provides } \\
\text { opportunities for on-the-job network } \\
\text { training. }\end{array}$ & 0.740 & - & - & - \\
\hline Partnering proactiveness & - & 0.803 & 0.735 & 0.505 \\
\hline $\begin{array}{l}\text { PP1: Our firm routinely gathers } \\
\text { information about prospective partners. }\end{array}$ & 0.689 & - & - & - \\
\hline $\begin{array}{l}\text { PP2: We use firms apart from our } \\
\text { existing partners to identify potential } \\
\text { partners. }\end{array}$ & 0.715 & - & - & - \\
\hline $\begin{array}{l}\text { PP3: Our firm judges in advance which } \\
\text { possible partners we can pursue. }\end{array}$ & 0.719 & - & - & - \\
\hline $\begin{array}{l}\text { PP4: We often initiate the creation of } \\
\text { important business networks. }\end{array}$ & 0.719 & - & - & - \\
\hline Supply chain competence & - & 0.871 & 0.869 & 0.629 \\
\hline $\begin{array}{l}\text { SCC5: Our ability in managing supply } \\
\text { chain inventory is excellent. }\end{array}$ & 0.769 & - & - & - \\
\hline $\begin{array}{l}\text { SCC6: Our ability to meet promised } \\
\text { delivery date is excellent. }\end{array}$ & 0.870 & - & - & - \\
\hline $\begin{array}{l}\text { SCC8: Our ability to issue advanced } \\
\text { notice on shipping delays is excellent. }\end{array}$ & 0.744 & - & - & - \\
\hline $\begin{array}{l}\text { SCC9: Our ability to enhance supply } \\
\text { chain's position in integrity is excellent. }\end{array}$ & 0.783 & - & - & - \\
\hline
\end{tabular}

Note: $\mathrm{CMIN} / \mathrm{df} 1.55, p<0.001, \mathrm{CFI}=0.92, \mathrm{RMSEA}=0.06$.

$\mathrm{CR}$, composite reliability; AVE, average variance extracted; $\mathrm{CFI}$, comparative fit index; RMSEA, root mean square error of approximation; df, degrees of freedom.

TABLE 3: Discriminant validity assessment.

\begin{tabular}{lccccc}
\hline Variable & AVE & CIMC & AMC & PP & SCC \\
\hline $\begin{array}{l}\text { Customer interaction management capability } \\
\text { (CIMC) }\end{array}$ & 0.541 & 0.736 & - & - & - \\
Alliance management capability (AMC) & 0.555 & 0.681 & 0.745 & - & - \\
Partnering proactiveness (PP) & 0.505 & 0.694 & 0.673 & 0.711 & - \\
Supply chain competence (SCC) & 0.629 & 0.587 & 0.648 & 0.574 & 0.793 \\
\hline
\end{tabular}

comparing the square of the root of the AVE with the interconstruct correlation coefficients and the square root of AVE should be greater than the interconstruct correlations (Fornell \& Larcker 1981:39). The results shown in Table 3 prove significant discriminant validity.

\section{Measurement model goodness-of-fit assessment}

Confirmatory factor analysis was used to categorise the variables (measurement model) and test the hypothesised conceptual model (structural path model). Confirmatory factor analysis was also conducted to confirm the structure of the measurement model using the comparative fit index 
TABLE 4: Result of the hypotheses testing.

\begin{tabular}{|c|c|c|c|c|c|}
\hline Hypothesis & Path & $\begin{array}{l}\text { Standard path } \\
\text { coefficient }\end{array}$ & $\begin{array}{c}\text { Standard } \\
\text { error }\end{array}$ & $t$ & $\begin{array}{l}\text { Test } \\
\text { result }\end{array}$ \\
\hline $\mathrm{H} 1$ & $\begin{array}{l}\text { Customer interaction } \\
\text { management capability } \rightarrow \\
\text { supply chain competence }\end{array}$ & $0.100 * * *$ & 0.023 & 4.348 & Accept \\
\hline $\mathrm{H} 2$ & $\begin{array}{l}\text { Alliance management } \\
\text { capability } \rightarrow \text { supply chain } \\
\text { competence }\end{array}$ & $0.418 * * *$ & 0.016 & 26.125 & Accept \\
\hline H3 & $\begin{array}{l}\text { Partnering proactiveness } \\
\rightarrow \text { supply chain } \\
\text { competence }\end{array}$ & $0.250 * * *$ & 0.079 & 3.14 & Accept \\
\hline
\end{tabular}

Note: Significance levels $* * *, p<0.001$.

(CFI), the root mean square error of approximation (RMSEA) and the Chi-square-degrees of freedom ratio $\left(c^{2} / \mathrm{df}\right)$ (Steiger 1990:175). Adequate model goodness-of-fit is obtained when cutoff values of 0.90 or more for the CFI index, RMSEA values less than 0.08 and $c^{2} / \mathrm{df}$ values lower than 3.0 (reasonable relative efficiency) and less than 2.0 (good fit) are required (Hu \& Bentler 1998:424; Segars \& Grover 1998:140). The results presented in Table 4 indicate a good fit of the hypothesised measurement model.

\section{Structural (path) analysis and hypothesis testing}

Because the study's measurement model fits reasonably well, it is reasonable to assume that there are sound theoretical foundations for the study. The constructs were converted to form the structural model through a path diagram so that the relationships between the variables can be tested. Hence the correlational associations of the measurement model were transformed into structural model relationships. The hypothesised causal relationships among the different constructs were validated using structural equation model (SEM) using Amos 24.0 software.

Table 4 presents a summary of the standardised structural path coefficient for $\mathrm{H} 1-\mathrm{H} 3$ hypotheses and as shown in Table 4 all hypotheses are fully supported $(p<0.001)$. As stated in the results, customer interaction management capability has a positive and significant effect on supply chain competence $(\beta=0.10, t=4.348, p<0.001)$, as stated in $\mathrm{H} 1$. The second hypothesis (H2) suggests that alliance management capability has a positive effect on supply chain competence and his hypothesis was also supported at 0.001 level of significance $(\beta=0.418, t=26.125)$. Alliance management capabilities have the greatest influence on supply chain competence. Hypothesis 3, which supposed that relational governance has a positive and significant influence on supply chain competence, was also empirically supported $(\beta=0.25, t=3.14)$. From the results presented, all the three hypotheses were empirically and significantly supported.

\section{Discussion and conclusion}

This study sought to investigate the relationship between COOC (customer interaction management capability, alliance management capability and relational governance) and supply competence. Building from the dynamic capabilities theory and the RBV, the three independent dimensions mentioned above were categorically referred to as COOC.
The results of this study demonstrate the critical role of organisational capabilities in achieving supply chain competence in Zimbabwean SMEs. The study proves that collaborative capabilities are central to the supply chain success of SMEs with the possibility of influencing also the firm's sustainable competitive advantage in line with the dynamic capabilities theory (Pooe \& Mahlangu 2017:245; Teece 2014:17). The study thus provided empirical support for the dynamic capabilities and the relational views of competitive advantage.

This study sheds light on the possibility of enhancing the overall supply chain competence of SMEs by establishing and empirically testing the relationships between COOC and supply chain competence. Supply chain competence can be achieved by strategic and outstanding customer interaction. When customer interactions are well managed, the firm can detect shift in customer perspectives and respond with the right product offerings, technologies, skills or knowledge (Forkman et al. 2016:190). This is central to the development of supply chain competences. In addition, the proper management of alliances has proved to be critical in fostering improved supply chain competence. The results of this study are consistent with the existing literature and the findings of Rai et al. (2006:225) who stated that because alliance management capability fosters the idiosyncratic exchange of knowledge and information between partners, it enhances supply chain management. Lastly, relational governance is also important in supply chain abilities development.

\section{Managerial implications}

Given the dynamism in the business environment, and the general lack of adequate resources by SMEs to finance growth, competitive advantage depends upon the firm ability to continuously develop organisational capabilities that enhance performance (Najib et al. 2017:574). This study offers valuable contributions for managers because it recommends ways to foster superior supply chain competence, which is a key driver of firm competitive advantage. The results from this study suggest that managers should steer up and refine their collaborative organisational capabilities to manage well their supply chain. The firm's interaction with its customers, its alertness to partnering opportunities and the manner in which it manages strategic alliances has been proved key to supply chain competence. In relation to specific managerial practices, owners and managers of SMEs should cultivate a culture that develops and empowers employees to collaborate with the external word, as this empowers the firm to competently manage its supply chain. Active participation in business networks and alliances will assist in improving firm supply chain integrity, delivery time, inventory management and shipping efficiency. These aspects are central to the supply chain competence of the firm. Management and owners of SMEs must also put in place systems to support the development of collaboration-oriented capabilities as these have proved to be 
critical for firms. Furthermore, it is important for SMEs to mobilise critical resources for the upgrade of networking and customer interaction technologies.

This study is not without limitations regarding the generalisation of the results. The dimensions in this study were defined primarily based on the provisions of existing literature. There is therefore a possibility that the critical elements of research constructs could have been missed in the process of defining and confining the research construct. Although due care was taken in the build-up to the research dimensions, the possibility of misspecifications cannot be ruled out completely. The other limitation to this study emanates from data collection and sampling. The methods of sampling and data collection have limitations, and these affect the generalisability of the results of this study. Further research is required to understand the antecedents of COOC and, additionally, such research explores supply chain competence in SMEs in a different way. There is also the need to assess the role of organisational capabilities according to the different sectoral and national contexts.

\section{Acknowledgements Competing interests}

The authors declare that they have no financial or personal relationships that may have inappropriately influenced them in writing this article.

\section{Authors' contributions}

D.P. was responsible for literature review and data analysis and refined the article for submission. W.M. was responsible for literature review and data collection and worked on the draft version.

\section{Disclaimer}

The views expressed in this article are the authors' own and do not represent an official position of the institution or funder.

\section{References}

Andaleeb, S.S., Rashid, M. \& Rahman, Q.A., 2016, 'A model of customer-centric banking practices for corporate clients in Bangladesh,' International Journal of Bank Marketing 34(4), 458-475. https://doi.org/10.1108/IJBM-10-2014-0156

Anderson, J.C. \& Gerbing, D.W., 1988, 'Structural equation modeling in practice: A review and recommended two-step approach', Psychological Bulletin 103(3), 411-423.

Babbie, E. \& Mouton, J., 2001, The Practice of Social Research, Oxford University Press, Cape Town.

Babbie, E. \& Mouton, J., 2007, 'Qualitative methods of data sampling', The Practice of Social Research 7, 187-193.

Babbie, E., 2005, The basics of research, Thomson Wadsworth, Belmont, CA.

Barney, J.B., 2001, "Is the resource-based "view" a useful perspective for strategic management research?', Academy of Management Review 26(1), 41-56.

Burns, N. \& Grove, S.K., 1993, The practice of nursing research: Conduct, critique and utilization, 2nd edn., W.B. Saunders, Philadelphia.

Burns, N. \& Grove, S.K., 2010, Understanding nursing research-eBook: Building an evidence-based practice, Elsevier Health Sciences, St Louis, MO.

Burns, R.P. \& Burns, R., 2008, Business research methods and statistics using SPSS, Sage, Thousand Oaks, CA

Büyüközkan, G. \& Göçer, F., 2018, 'Digital supply chain: Literature review and a proposed framework for future research', Computers in Industry 97, 157-177. https://doi.org/10.1016/j.compind.2018.02.010

C. Longhi (eds.), Markets and organization, pp. 281-302, Springer, Berlin, Heidelberg.
Castro, I. \& Roldán, J.L., 2015, 'Alliance portfolio management: Dimensions and performance', European Management Review 12(2), 63-81. https://doi.org/ 10.1111/emre.12042

Chan, A.T., Ngai, E.W. \& Moon, K.K., 2017, 'The effects of strategic and manufacturing flexibilities and supply chain agility on firm performance in the fashion industry', European Journal of Operational Research 259(2), 486-499. https://doi. org/10.1016/j.ejor.2016.11.006

Chen, D.Q., Preston, D.S. \& Swink, M., 2015, 'How the use of big data analytics affects value creation in supply chain management', Journal of Management Information Systems 32(4), 4-39. https://doi.org/10.1080/07421222.2015.1138364

Coates, T.T. \& McDermott, C.M., 2002, 'An exploratory analysis of new competencies: A resource based view perspective', Journal of Operations Management 20(5), 435-450. https://doi.org/10.1016/S0272-6963(02)00023-2

Cooper, D.R. \& Schindler, P.S., 2016, Research methods in business administration, 12th edn., McGraw-Hill, Porto Alegre.

Costantino, F., Di Gravio, G., Shaban, A. \& Tronci, M., 2015, 'The impact of information sharing on ordering policies to improve supply chain performances', Computers \& Industrial Engineering 82, 127-142. https://doi.org/10.1016/j.cie.2015.01.024

De Wit, G. \& De Kok, J., 2014, 'Do small businesses create more jobs? New evidence for Europe', Small Business Economics 42(2), 283-295. https://doi.org/10.1007/ s11187-013-9480-1

Dosi, G. \& Teece, D.J., 1998, 'Organizational competencies and the boundaries of the firm' in R. Arena \& Eisenhardt, K.M. \& Martin, J.A., 2000, 'Dynamic capabilities: What are they?', Strategic Management Journal 21, 1105-1121. https://doi.org/10.1002/10970266(200010/11)21:10/11\%3C1105::AID-SMJ133\%3E3.0.CO;2-E

Eisenhardt, K.M., Furr, N.R. \& Bingham, C.B., 2010, 'Crossroads-Microfoundations of performance: Balancing efficiency and flexibility in dynamic environments', Organization Science 21(6), 1263-1273.

Forkmann, S., Henneberg, S.C., Naudé, P. \& Mitrega, M., 2016, 'Supplier relationship management capability: A qualification and extension', Industrial Marketing Management 57, 185-200. https://doi.org/10.1016/j.indmarman.2016.02.003

Fornell, C. \& Larcker, D.F., 1981, 'Evaluating structural equation models with unobservable variables and measurement error', Journal of Marketing Research 18(1), 39-50. https://doi.org/10.1177/002224378101800104

Franco, M. \& Haase, H., 2015, 'University-industry cooperation: Researchers' motivations and interaction channels', Journal of Engineering and Technology Management 36, 41-51. https://doi.org/10.1016/j.jengtecman.2015.05.002

Frank, H. \& Roessl, D., 2015, 'Problematization and conceptualization of "entrepreneurial SME Management" as a field of research: Overcoming the sizebased approach', Review of Managerial Science 9(2), 225-240.

Giri, B.C. \& Sarker, B.R., 2017, 'Improving performance by coordinating a supply chain with third party logistics outsourcing under production disruption', Computers \& Industrial Engineering 103, 168-177. https://doi.org/10.1016/j.cie.2016.11.022

Hair, J., Anderson, R.O. \& Tatham, R., 1987, Multidimensional data analysis, Macmillan, New York.

Henseler, J., Ringle, C.M. \& Sarstedt, M., 2015, 'A new criterion for assessing discriminant validity in variance-based structural equation modeling', Journal of the Academy of Marketing Science 43(1), 115-135. https://doi.org/10.1007/s11747-014-0403-8

Homburg, C., Jozić, D. \& Kuehnl, C., 2017, 'Customer experience management: Toward implementing an evolving marketing concept', Journal of the Academy of Marketing Science 45(3), 377-401. https://doi.org/10.1007/s11747-015-0460-7

Hooley, G., Broderick, A. \& Möller, K., 1998, 'Competitive positioning and the resourcebased view of the firm', Journal of Strategic Marketing 6(2), 97-116. https://doi. org/10.1080/09652549800000003

Hu, L.T. \& Bentler, P.M., 1998, 'Fit indices in covariance structure modeling: Sensitivity to underparameterized model misspecification', Psychological Methods 3(4), 424. https://doi.org/10.1037/1082-989X.3.4.424

Hugo, M.H., 2018, Essentials of supply chain management, John Wiley \& Sons, Hoboken, NJ.

Kale, P., Singh, H. \& Raman, A.P., 2009, 'Don't integrate your acquisitions, partner with them', Harvard Business Review 87(12), 109-115.

Kato, M. \& Charoenrat, T., 2018, 'Business continuity management of small and medium sized enterprises: Evidence from Thailand', International Journal of Disaster Risk Reduction 27, 577-587.

Kim, M. \& Chai, S., 2017, 'The impact of supplier innovativeness, information sharing and strategic sourcing on improving supply chain agility: Global supply chain perspective', International Journal of Production Economics 187, 42-52. https:// perspective', International Journal of
doi.org/10.1016/j.ijpe.2017.02.007

Kohtamäki, M., Rabetino, R. \& Möller, K., 2018, 'Alliance capabilities: A systematic review and future research directions', Industrial Marketing Management 68 188-201. https://doi.org/10.1016/j.indmarman.2017.10.014

Lee, S.M. \& Rha, J.S., 2016, 'Ambidextrous supply chain as a dynamic capability: Building a resilient supply chain', Management Decision 54(1), 2-23. https://doi. org/10.1108/MD-12-2014-0674

Lin, C.H.V., Sanders, K., Sun, J.M.J., Shipton, H. \& Mooi, E.A., 2016, 'From customeroriented strategy to organizational financial performance: The role of human
resource management and customer-linking capability', British Journal of Management 27(1), 21-37. https://doi.org/10.1111/1467-8551.12142

Liu, C.H., 2017, 'The relationships among intellectual capital, social capital, and performance-The moderating role of business ties and environmental uncertainty', Tourism Management 61,553-561.https://doi.org/10.1016/j.tourman.2017.03.017 
Löfsten, H., 2016, 'Business and innovation resources: Determinants for the survival of new technology-based firms', Management Decision 54(1), 88-106.

Luo, X., Rindfleisch, A. \& Tse, D.K., 2007, 'Working with rivals: The impact of competitor alliances on financial performance', Journal of Marketing Research 44(1), 73-83. https://doi.org/10.1509/jmkr.44.1.73

Macheka, L., Manditsera, F.A., Ngadze, R.T., Mubaiwa, J. \& Nyanga, L.K., 2013 'Barriers, benefits and motivation factors for the implementation of food safety management system in the food sector in Harare Province, Zimbabwe', Food Control 34(1), 126-131.

Manuere, F. \& Majoni, T., 2016, 'The concept of corporate social responsibility among SMEs in Zimbabwe', International Journal of Latest Research in Engineering and Technology 2(2), 63-71.

Martinez-Conesa, I., Soto-Acosta, P. \& Carayannis, E.G., 2017, 'On the path towards open innovation: Assessing the role of knowledge management capability and environmental dynamism in SMEs', Journal of Knowledge Management 21(3), 553-570. https://doi.org/10.1108/JKM-09-2016-0403

Mattsson, L.G., Corsaro, D. \& Ramos, C., 2015, 'Sense-making in business markets-the interplay between cognition, action and outcomes', Industrial Marketing Management 48, 4-11. https://doi.org/10.1016/j.indmarman.2015.03.003

Migdadi, M.M., Zaid, M.K.S.A., Yousif, M. \& Almestarihi, R.D., 2018, 'An empirical examination of collaborative knowledge management practices and organisational performance: The mediating roles of supply chain integration and knowledge quality', International Journal of Business Excellence 14(2), 180-211. https://doi. quality', International Journal of
org/10.1504/IJBEX.2018.089149

Mukerjee, K., 2012, 'Customer experience management: A framework for successfully managing the customer experience', SIBM 4, 55-65.

Najafi-Tavani, Z., Robson, M.J., Zaefarian, G., Andersson, U. \& Yu, C., 2018, 'Building subsidiary local responsiveness:(When) does the directionality of intrafirm knowledge transfers matter?', Journal of World Business 53(4), 475-492. https:// doi.org/10.1016/j.jwb.2018.01.004

Najib, M.F., Kartini, D., Suryana, Y. \& Sari, D., 2017, 'Market orientation, buyer-supplie relationship and firm performance with dynamic capabilities as an intervening variable: A research model', International Journal of Business and Globalisation 19(4), 567-582.

Ngai, E.W., Chau, D.C. \& Chan, T.L.A., 2011, 'Information technology, operational, and management competencies for supply chain agility: Findings from case studies' The Journal of Strategic Information Systems 20(3), 232-249. https://doi. org/10.1016/j.jsis.2010.11.002

Niesten, E. \& Jolink, A., 2015, 'The impact of alliance management capabilities on alliance attributes and performance: A literature review', International Journal of Management Reviews 17(1), 69-100. https://doi.org/10.1111/ijmr.12037

Niesten, E., Jolink, A., De Sousa Jabbour, A.B.L., Chappin, M. \& Lozano, R., 2017 'Sustainable collaboration: The impact of governance and institutions on sustainable performance', Journal of Cleaner Production 155, 1-6.

Nyangara, D., 2013, 'SME lending: Do lending technologies matter? Sample evidence from Zimbabwe', World Review of Business Research 3(4), 219-230.

O'Dwyer, M. \& Gilmore, A., 2018, 'Value and alliance capability and the formation of strategic alliances in SMEs: The impact of customer orientation and resource optimisation', Journal of Business Research 87, 58-68. https://doi.org/10.1016/j. jbusres.2018.02.020

Osano, H.M. \& Languitone, H., 2016, 'Factors influencing access to finance by SMEs in Mozambique: case of SMEs in Maputo central business district', Journal of Innovation and Entrepreneurship 5(1), 13-29.

Pang, Z., Chen, Q., Han, W. \& Zheng, L., 2015, 'Value-centric design of the internet-of things solution for food supply chain: Value creation, sensor portfolio and information fusion', Information Systems Frontiers 17(2), 289-319. https://do org/10.1007/s10796-012-9374-9

Pangarkar, N., Yuan, L. \& Hussain, S., 2017, 'Too much of a good thing? Alliance portfolio size and alliance expansion', European Management Journal 35(4), 477-485. https://doi.org/10.1016/j.emj.2016.09.006

Parida, V. \& Örtqvist, D., 2015, 'Interactive effects of network capability, ICT capability, and financial slack on technology-based small firm innovation performance', Journal of Small Business Management 53(S1), 278-298.

Peck, F., Jackson, K. \& Mulvey, G., 2018, 'Regulation and growth-oriented smal businesses in North-West England', Journal of Small Business and Enterprise Development 25(2), 294-312.

Pettersson, A.I. \& Segerstedt, A., 2013, 'Measuring supply chain cost', Internationa Journal of Production Economics 143(2), 357-363. https://doi.org/10.1016/j. ijpe.2012.03.012

Polit, D.F. \& Hungler, B.P., 1999, Nursing research principles and methods, Lippincott Williams and Wilkins, Philadelphia.

Pooe, R.I.D. \& Mahlangu, D., 2017, 'Enhancing SME performance through supply chain integration, collaborative planning, and supply chain capabilities', Journal of Contemporary Management 14(1), 238-269.
Pooe, R.I.D. \& Mathu, K., 2011, 'The South African coal mining industry: A need for a more efficient and collaborative supply chain', Journal of Transport and Supply Chain Management 5(1), 316-336. https://doi.org/10.4102/jtscm.v5i1.80

Racela, O.C., 2014, 'Customer orientation, innovation competencies, and firm performance: A proposed conceptual model', Procedia-Social and Behavioral Sciences 148, 16-23. https://doi.org/10.1016/j.sbspro.2014.07.010

Rahmandad, H. \& Repenning, N., 2016, 'Capability erosion dynamics', Strategic Management Journal 37(4), 649-672.

Rai, A., Patnayakuni, R. \& Seth, N., 2006, 'Firm performance impacts of digitally enabled supply chain integration capabilities', MIS Quarterly 30(2), 225-246. https://doi.org/10.2307/25148729

Raja, J.Z., Green, S.D. \& Leiringer, R., 2010, 'Concurrent and disconnected change programmes: Strategies in support of servitization and the implementation of business partnering', Human Resource Management Journal 20(3), 258-276. https://doi.org/10.1111/j.1748-8583.2009.00124.x

Ramanathan, U. \& Muyldermans, L., 2010, 'Identifying demand factors for promotional planning and forecasting: A case of a soft drink company in the UK', Internationa Journal of Production Economics 128(2), 538-545. https://doi.org/10.1016/j. ijpe.2010.07.007

Ramon-Jeronimo, J.M., Florez-Lopez, R. \& Ramon-Jeronimo, M.A., 2017 'Understanding the generation of value along supply chains: Balancing control information and relational governance mechanisms in downstream and upstream relationships', Sustainability 9(8), 1487-1518. https://doi.org/10.3390/su9081487

Sarkar, M.B., Aulakh, P.S. \& Madhok, A., 2009, 'Process capabilities and value generation in alliance portfolios', Organization Science 20(3), 583-600. https:// generation in alliance portfolios',
doi.org/10.1287/orsc.1080.0390

Segars, A.H. \& Grover, V., 1998, 'Strategic information systems planning success: An investigation of the construct and its measurement', MIS Quarterly 22(2), 139163. https://doi.org/10.2307/249393

Sluyts, K., Matthyssens, P., Martens, R. \& Streukens, S., 2011, 'Building capabilities to manage strategic alliances', Industrial Marketing Management 40(6), 875-886. https://doi.org/10.1016/j.indmarman.2011.06.022.

Smit, Y. \& Watkins, J.A, 2012, 'A literature Review of Small and Medium Enterprises (SME) risk management practices in South Africa', Africa Journal of Busines. Management 6(21), 6324-6330.

Steiger, J.H., 1990, 'Structural model evaluation and modification: An interval estimation approach', Multivariate Behavioral Research 25(2), 173-180. https:// doi.org/10.1207/s15327906mbr2502_4

Storbacka, K., 2012, 'Strategic account management programs: Alignment of design elements and management practices', Journal of Business \& Industrial Marketing 27(4), 259-274. https://doi.org/10.1108/08858621211221643

Swafford, P.M., Ghosh, S. \& Murthy, N., 2008, 'Achieving supply chain agility through IT integration and flexibility', International Journal of Production Economics 116(2), 288-297. https://doi.org/10.1016/j.ijpe.2008.09.002

Tan, M. \& Liu, Z., 2014, 'Paths to success: An ambidexterity perspective on how responsive and proactive market orientations affect SMEs' business performance', Journal of Strategic Marketing 22(5), 420-441. https://doi.org/10.1080/096525 $4 \mathrm{X} .2013 .876084$

Teece, D.J., 2012, 'Dynamic capabilities: Routines versus entrepreneurial action' Journal of Management Studies 49(8), 1395-1401. https://doi.org/10.1111/j. 1467-6486.2012.01080.x

Teece, D.J., 2014, 'A dynamic capabilities-based entrepreneurial theory of the multinational enterprise', Journal of International Business Studies 45(1), 8-37. https://doi.org/10.1057/jibs.2013.54

Tsou, H.T. \& Huang, Y.W., 2018, 'Empirical study of the affecting statistical education on customer relationship management and customer value in $\mathrm{Hi}$ tech industry', Eurasia Journal of Mathematics, Science and Technology Education 14(4), 1287-1294.

Valença, G. \& Alves, C., 2017, 'A theory of power in emerging software ecosystems formed by small-to-medium enterprises', Journal of Systems and Software 134 76-104. https://doi.org/10.1016/j.jss.2017.08.044

Wang, Y. \& Feng, H., 2012, 'Customer relationship management capabilities: Measurement, antecedents and consequences', Management Decision 50(1), 115-129.

Wang, Y. \& Rajagopalan, N., 2015, 'Alliance capabilities: Review and research agenda' Journal of Management 41(1), 236-260.https://doi.org/10.1177/01492063 14557157

Wernerfelt, B., 1984, 'A resource based view of the firm', Strategic Management Journal 5(2), 171-180. https://doi.org/10.1002/smj.4250050207

Wiklund, J. \& Shepherd, D., 2003, 'Knowledge-based resources, entrepreneurial orientation, and the performance of small and medium-sized businesses', Strategic Management Journal 24(13), 1307-1314. https://doi.org/10.1002/smj.360

Winter, S.G., 2003, 'Understanding dynamic capabilities', Strategic Management Journal 24(10), 991-995. https://doi.org/10.1002/smj.318 